\title{
Article \\ Control of Oxygen Impurities in a Continuous-Feeding Czochralski-Silicon Crystal Growth by the Double-Crucible Method
}

\author{
Wenhan Zhao, Jiancheng Li and Lijun Liu *(D)
}

Citation: Zhao, W.; Li, J.; Liu, L. Control of Oxygen Impurities in a Continuous-Feeding CzochralskiSilicon Crystal Growth by the Double-Crucible Method. Crystals 2021, 11, 264. https://doi.org/ $10.3390 /$ cryst11030264

Academic Editor: Evgeniy N. Mokhov

Received: 29 January 2021 Accepted: 24 February 2021 Published: 8 March 2021

Publisher's Note: MDPI stays neutral with regard to jurisdictional claims in published maps and institutional affiliations.

Copyright: (c) 2021 by the authors. Licensee MDPI, Basel, Switzerland. This article is an open access article distributed under the terms and conditions of the Creative Commons Attribution (CC BY) license (https:/ / creativecommons.org/licenses/by/ $4.0 /)$.
Key Laboratory of Thermo-Fluid Science and Engineering, Ministry of Education, School of Energy and Power Engineering, Xi'an Jiaotong University, Xi'an 710049, China; zwh.xjtu@stu.xjtu.edu.cn (W.Z.); ljcheng@stu.xjtu.edu.cn (J.L.)

* Correspondence: ljliu@mail.xjtu.edu.cn; Tel.: +86-29-82663443

\begin{abstract}
The continuous-feeding Czochralski method is a cost-effective method to grow single silicon crystals. An inner crucible is used to prevent the un-melted silicon feedstock from transferring to the melt-crystal interface in this method. A series of global simulations were carried out to investigate the impact of the inner crucible on the oxygen impurity distributions at the melt-crystal interface. The results indicate that, the inner crucible plays a more important role in affecting the $\mathrm{O}$ concentration at the melt-crystal interface than the outer crucible. It can prevent the oxygen impurities from being transported from the outer crucible wall effectively. Meanwhile, it also introduces as a new source of oxygen impurity in the melt, likely resulting in a high oxygen concentration zone under the melt-crystal interface. We proposed to enlarge the inner crucible diameter so that the oxygen concentration at the melt-crystal interface can be controlled at low levels.
\end{abstract}

Keywords: computer simulation; impurities; continuous-feeding Czochralski method; heat transfer; double crucible technique

\section{Introduction}

The continuous-feeding Czochralski method (CCZ) is an effective method to produce single crystals, especially for crystalline silicon (Si) [1,2]. Compared with the standard Czochralski (CZ) method, it has many advantages. For example, since silicon melt can be replenished continuously during a CCZ crystal growth process, the melt volume can remain limited and unchanged in the crucible so that the melt flow becomes stable and the unsteady kinetics of the melt will be suppressed. In addition, continuous recharging of the melt allows for stable control of dopant [3], impurities, and resistivity distribution in a growing crystal, which helps to improve the crystal quality $[4,5]$. Therefore, it is a very promising technology to produce high-quality crystals at a low cost. However, the CCZ grown crystal exhibits special defects, which are considered to be related to the relatively high hydrogen content of the recharged Si granules [6]. These defects lead to serious challenges in the application of CCZ single crystals of silicon in electronic devices. Fortunately, with respect to the solar application, they are considered unlikely to have an adverse effect on solar cell performance [7]. In recent years, with a strong demand for producing n-type crystals for high-efficiency solar cells, the CCZ method has become very promising [8-10]. It is predicted that the CCZ method will make significant gains in the market share over conventional $\mathrm{CZ}$ in the next $3-5$ years [11].

The growth of crystalline silicon is invariably accompanied by impurities transport, such as oxygen $(\mathrm{O})$, carbon $(\mathrm{C})$, and other related products, from reactions [12]. Special attention has been paid to, and, therefore, many researches [13-22] have been contributed, the control $\mathrm{O}$ concentration in the melt and growing crystals. In the growth process of some conventional methods, it affects the formation of micro-defects in the growing crystal 
in a complex manner [13]. In the CCZ process, to prevent the unmelted silicon feedstock from transferring to the melt-crystal (m-c) interface, an inner quartz crucible is usually placed on the bottom of the outer quartz crucible [23]. Since O impurities are dissolved from the quartz crucible wall, a new source of $\mathrm{O}$ impurity is thus introduced. Therefore, it is important to investigate the impact of the inner crucible on the $\mathrm{O}$ distributions in the melt, especially at the $\mathrm{m}-\mathrm{c}$ interface, because $\mathrm{O}$ impurities will enter the crystal through the $\mathrm{m}$-c interface. If the initial $\mathrm{O}$ concentration of n-type $\mathrm{CCZ}$ wafers is too high, the solar cell efficiency will be reduced [24]. Previous research indicates that the inner crucible is the main reason for this phenomenon, and the $\mathrm{O}$ concentration at the $\mathrm{m}-\mathrm{c}$ interface will increase in the double-crucible CCZ method [25]. Providing an electromagnetic stirring of the melt is an effective way to decrease the $\mathrm{O}$ concentration at the $\mathrm{m}$-c interface [26]. However, the complexity of the crystal growth systems and the cost will be increased by this method.

This study aims to find an effective way to reduce the $\mathrm{O}$ concentration by the doublecrucible CCZ method. The impact of the inner crucible was investigated by global simulations, including coupled $\mathrm{O}$ and $\mathrm{C}$ transport, which have been widely used to study the O distributions in a crystal growth process $[16,20,27-33]$. The influence mechanism of the inner crucible on the $\mathrm{O}$ concentration in the melt was analyzed. Based on this research, an effective method to decrease the O distribution in the double-crucible CCZ method was proposed.

\section{Problem Description and Mathematical Models}

\subsection{Furnace Configuration}

A schematic diagram of the CCZ furnace for industrial manufacture is given in Figure 1. The diameter of the crystal was $200 \mathrm{~mm}$. The crystal length was $600 \mathrm{~mm}$. The inner and outer crucible diameters were $300 \mathrm{~mm}$ and $540 \mathrm{~mm}$, respectively. To prevent the un-melted silicon feedstock from transferring to the m-c interface, an inner quartz crucible was placed on the bottom of the outer quartz crucible. The main dimensions of the CCZ furnace are listed in Table 1.

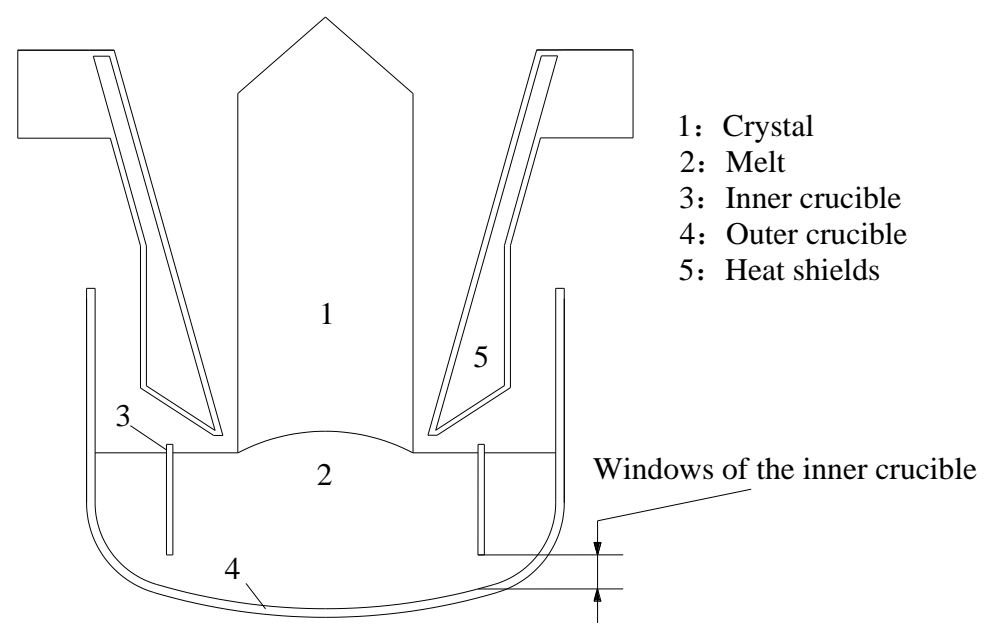

Figure 1. Schematic diagram of the continuous-feeding Czochralski method (CCZ) furnace with double crucibles.

Table 1. The dimensions of the continuous-feeding Czochralski method (CCZ) furnace.

\begin{tabular}{cccc}
\hline Crystal Diameter (mm) & Crystal Length (mm) & $\begin{array}{c}\text { Diameter of Inner } \\
\text { Crucible (mm) }\end{array}$ & $\begin{array}{c}\text { Diameter of Outer } \\
\text { Crucible (mm) }\end{array}$ \\
\hline 200 & 600 & 300 & 540 \\
\hline
\end{tabular}


In our investigation, we compared the case of the conventional $\mathrm{CZ}$ method with a single crucible (the single-crucible case) and the proposed CCZ method with two crucibles (the double-crucible case). For the single-crucible case, the crystal and crucible rotation rates were set as $12 \mathrm{rpm}$ and $-6 \mathrm{rpm}$, respectively. For the double-crucible case, the rotation rates of crystal and crucible were set as $12 \mathrm{rpm}$ and $-4 \mathrm{rpm}$, respectively.

\subsection{Numerical Modeling}

A series of global simulations were carried out in this study. An in-house software (CGeMoS) which has been developed and used in our researches $[16,27,28,34-36]$ for more than 18 years (see http:/ / cgsolar.xjtu.edu.cn/, accessed on 29 January 2021), was applied in our investigation. A grid independence test was carried out for our simulations, and the total grid number was about 60,000. The latent heat released at the m-c interface was taken into account. A dynamic meshing technique was employed to get the m-c interface position that coincides with the isotherm of $1685 \mathrm{~K}$.

For O calculation, a well-developed global model of coupled $\mathrm{O}$ and $\mathrm{C}$ transport in the whole furnace was employed to study the impurities transportation in the furnace $[29,30]$. For the governing equations and boundary conditions of the $\mathrm{O}$ and $\mathrm{C}$ transport model, please refer to [30]. The global model has been validated in previous researches $[16,18]$.

\section{The Effect of Inner Crucible on the O Distributions in Melt}

\subsection{Comparison of O Distributions in the Melt between Single-Crucible and Double-Crucible Cases}

Since the $\mathrm{O}$ is dissolved from the quartz crucible wall, an extra $\mathrm{O}$ source is introduced when an inner crucible is placed in the outer crucible. This may lead to the increase in $\mathrm{O}$ concentration in the melt. However, it is the $\mathrm{O}$ concentration at the $\mathrm{m}-\mathrm{c}$ interface that affects the $\mathrm{O}$ concentration in the growing crystal. Therefore, we needed to investigate the impact of the inner crucible on the $\mathrm{O}$ concentration at the $\mathrm{m}$-c interface. For this purpose, we first carried out a series of simulations to compare the $\mathrm{O}$ concentration at the $\mathrm{m}$-c interface between the case with a single-crucible and the case with a double-crucible.

Temperature distributions in the silicon melt using the single-crucible and doublecrucible methods are shown in Figure 2. It was found that the highest melt temperature increased by about $14 \mathrm{~K}$ in the double-crucible case. This is because that the thermal conductivity of the inner quartz crucible is much smaller than that of the silicon melt. The introduction of the inner crucible in the melt makes the heat transferred more difficult from the outer crucible to the $\mathrm{m}$-c interface, and more oxygen is released from the crucible wall with a higher temperature.

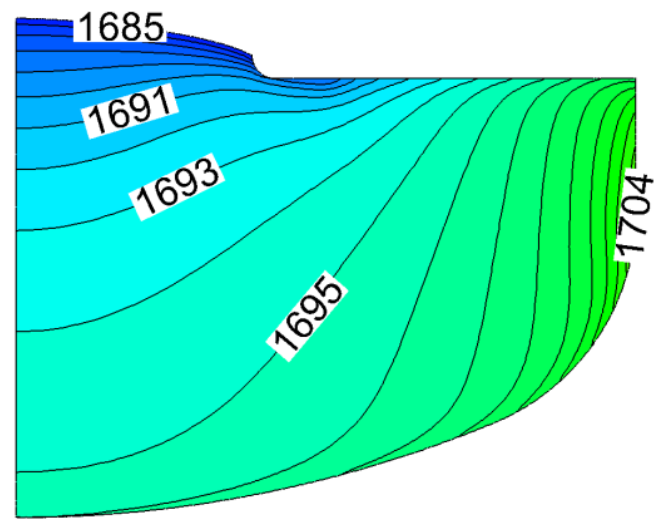

(a) single-crucible case

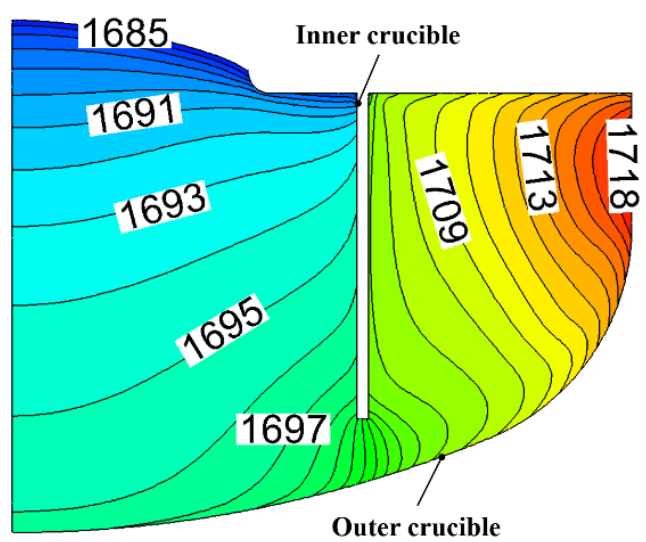

(b) double-crucible case

Figure 2. Temperature distributions (K) in the melt: (a) the case with the conventional single-crucible method, (b) the case with the double-crucible method. 
The stream function and $\mathrm{O}$ concentration in the melt in the single-crucible and doublecrucible cases are shown in Figure 3. The $\mathrm{O}$ distribution patterns in the melt were similar to the melt flow patterns, which indicates that the $\mathrm{O}$ transportation is affected by the melt flow remarkably. For the single-crucible case, there were two vortexes in the melt, which were driven by thermal buoyancy, as shown in the left part of Figure 3a. Oxygen impurities dissolved from the crucible bottom wall were transported to the crucible sidewall by the melt flow, resulting in a high $\mathrm{O}$ concentration near the crucible sidewall. Then, with the interaction between the outer and inner vortexes, oxygen impurities were transported to the $\mathrm{m}-\mathrm{c}$ interface by the inner vortex. A low $\mathrm{O}$ concentration zone was, therefore, located right under the $\mathrm{m}-\mathrm{c}$ interface. Compared with the high $\mathrm{O}$ concentration near the crucible wall, $\mathrm{O}$ concentration under the m-c interface decreased by about $60 \%$. Obviously, the flow patterns in the single-crucible case are beneficial to reduce the $\mathrm{O}$ concentration at the $\mathrm{m}$-c interface. While for the double-crucible case, as shown in Figure 3b, high O concentration zones were observed near both the inner and outer crucible walls. Just like the single-crucible case, $\mathrm{O}$ impurities dissolved from the outer crucible wall were transported by the melt flow from the crucible bottom to the crucible sidewall. Melt with a high $\mathrm{O}$ concentration near the outer crucible wall was blocked by the inner crucible, which is helpful to decrease the $\mathrm{O}$ concentration at the m-c interface. However, melt with a high $\mathrm{O}$ concentration near the inner wall of the inner crucible can be transported to the m-c interface directly by the vortex inside the inner crucible, which may lead to the increase in $\mathrm{O}$ concentration at the $\mathrm{m}-\mathrm{c}$ interface. Compared with the single-crucible case, $\mathrm{O}$ concentration under the $\mathrm{m}$-c interface increased from 15 ppma to 19 ppma, which indicates that the $\mathrm{O}$ concentration at the $\mathrm{m}-\mathrm{c}$ interface will increase in the CCZ crystal growth process with double crucibles. This result agrees well with the research reported in [25].

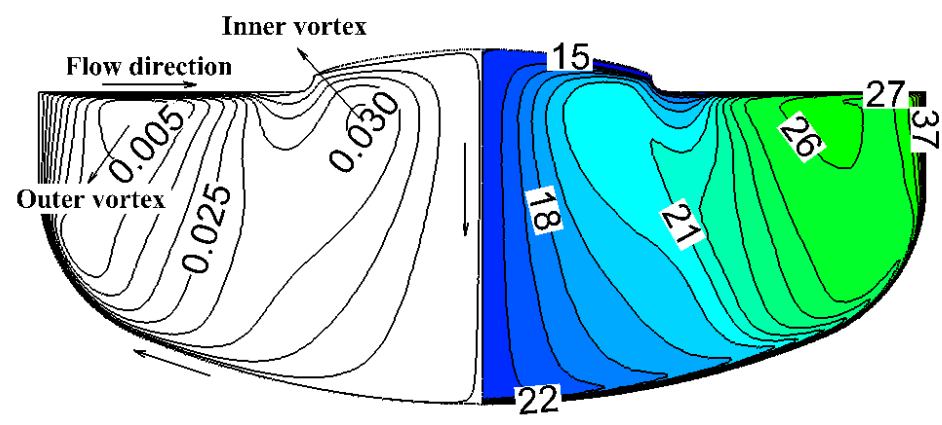

(a) single-crucible case

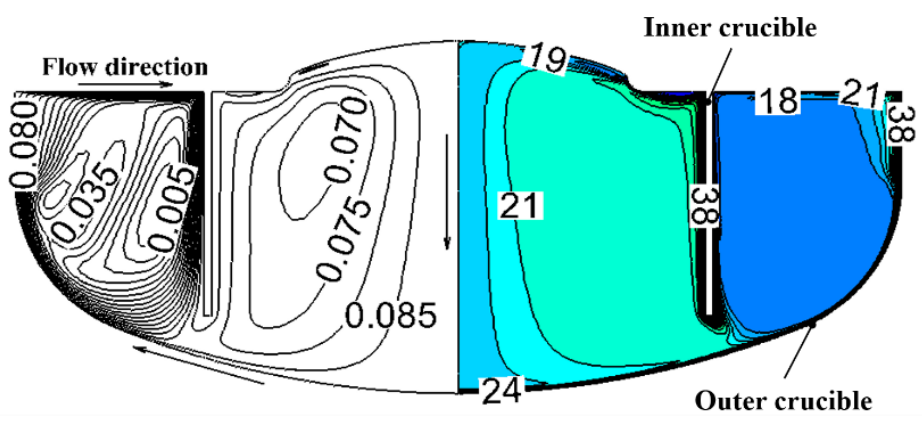

(b) double-crucible case

Figure 3. The stream function (left) and oxygen concentration (right, ppma) in the melt: (a) the case with the conventional single-crucible method, $(\mathbf{b})$ the case with the double-crucible method.

To clarify if this is a general conclusion for the CCZ method with double-crucible, we compared the O distributions at the crucible walls, as shown in Figure 4, for both cases with a single crucible and with double crucibles, which act as the origins of oxygen impurities. From the results shown in Figure 4, we can see that the oxygen concentration at the outer 
crucible walls was higher and the oxygen concentration at the inner crucible walls was lower in the double-crucible case than that in the single crucible case. Since O impurities dissolve from both the inner and outer crucible walls, it is essential to make clear which crucible is the dominant source of oxygen impurities transported to the m-c interface.

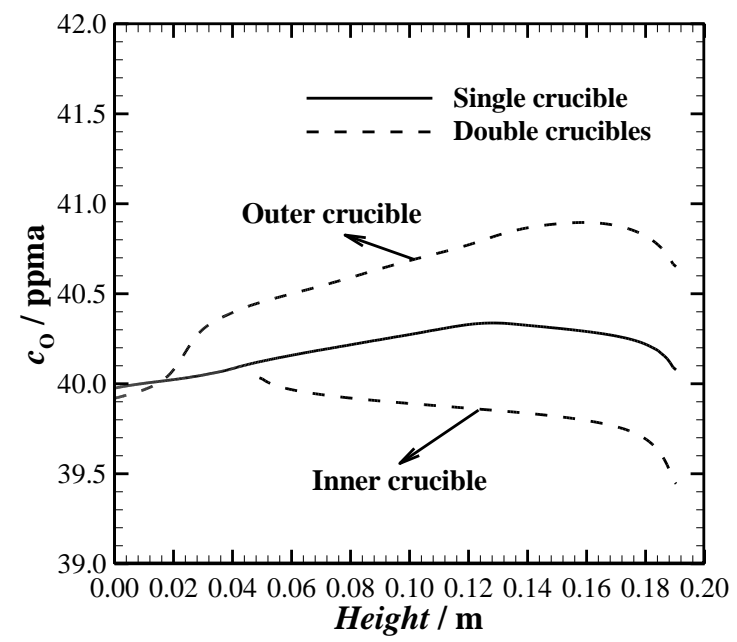

Figure 4. The oxygen distribution (ppma) at crucible walls.

\subsection{Study of the O Source at the Melt-Crystal Interface with Double-Crucible Method}

To make clear which crucible is the dominant source of oxygen impurities transported to the m-c interface in the double-crucible CCZ method, we investigated the impact of the inner crucible and the outer crucible, respectively, on the $\mathrm{O}$ concentration at the $\mathrm{m}-\mathrm{c}$ interface. For the sake of convenience in our numerical investigation, we introduced a concept of a virtual coating layer that is of no thickness and no oxygen dissolution. For example, when the inner crucible walls are covered with the virtual coating layer, there is no oxygen dissolved into the melt from the inner crucible. Therefore, the outer crucible becomes the unique source of oxygen impurities.

In Figure 5a, we show the O distribution in the melt for the case in which the outer crucible was covered by this virtual coating layer, which means that the inner crucible was the unique source of oxygen impurities in the melt. Compared with the results in Figure $3 b$, we found that the $\mathrm{O}$ concentration under the m-c interface only slightly decreased. Correspondingly, in Figure 5b, we show the O distribution in the melt for the case in which the inner crucible was covered by this virtual coating layer, which means that the outer crucible was the unique source of oxygen impurities in the melt. It is obviously found in this case that the $\mathrm{O}$ concentration under the $\mathrm{m}$-c interface was remarkably reduced as compared to the results shown in Figures $3 b$ and $5 a$. In Figure 6, we compared the impact of the inner crucible and outer crucible on the oxygen distribution at the $\mathrm{m}-\mathrm{c}$ interface. The results verified that the inner crucible can effectively prevent the $\mathrm{O}$ impurities dissolved from the outer crucible walls from being transported to the $\mathrm{m}$-c interface, but the inner crucible itself acts as the dominant source of $\mathrm{O}$ impurities transported to the $\mathrm{m}-\mathrm{c}$ interface. Therefore, the design of the inner crucible and control of the melt flow in the inner crucible are the key factors to reduce the $\mathrm{O}$ concentration at the $\mathrm{m}$-c interface in the CCZ double-crucible method. 


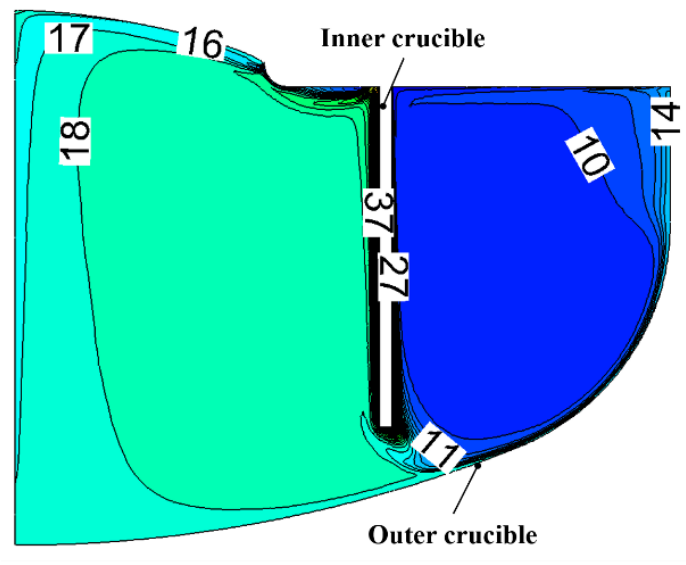

(a) oxygen only from the inner crucible walls

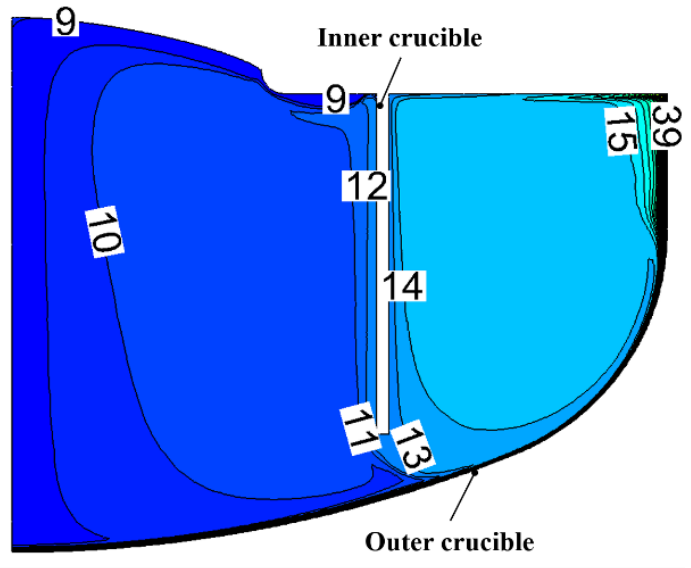

(b) oxygen only from the outer crucible walls

Figure 5. The $\mathrm{O}$ distribution (ppma) in the melt: (a) there is no oxygen dissolved into the melt from the outer crucible and the inner crucible is the unique source of oxygen impurities, (b) there is no oxygen dissolved into the melt from the inner crucible and the outer crucible is the unique source of oxygen impurities.

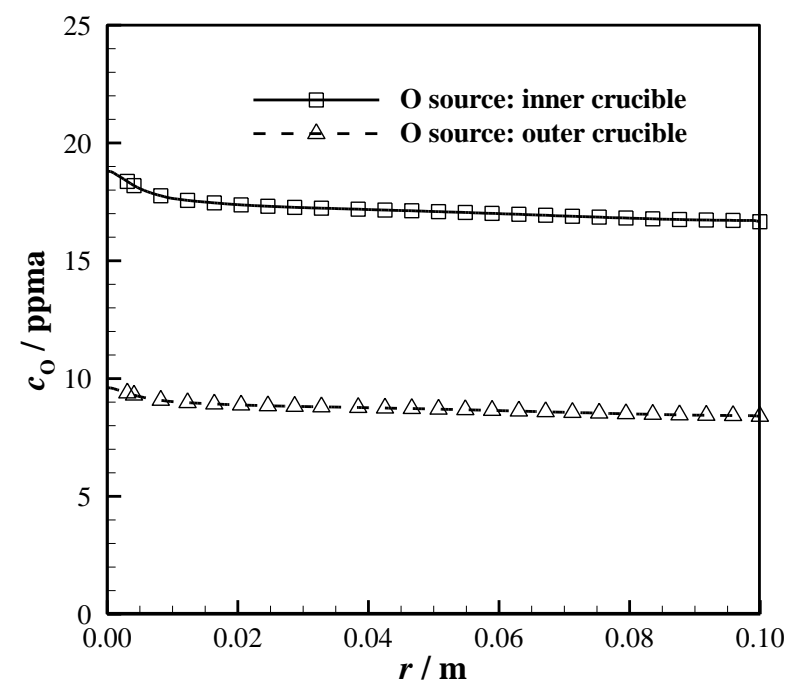

Figure 6. Impacts of the inner crucible and outer crucible on the oxygen distribution (ppma) at the $\mathrm{m}-\mathrm{c}$ interface.

\subsection{Approach to Decrease O Distributions at the m-c Interface by Double-Crucible Method}

Based on our research, the inner crucible was the dominant source of oxygen impurities transported to the $\mathrm{m}$-c interface, and the melt flow inside the inner crucible plays a key role in transporting the oxygen dissolved from the crucible walls to the $\mathrm{m}$-c interface. Therefore, we proposed an approach with a larger inner crucible in the CCZ method to reduce the oxygen content in the growing crystals. We carried out numerical simulations to verify our proposed approach.

Except for the case with an inner crucible diameter of $300 \mathrm{~mm}$, as we have investigated in detail, global simulations of the thermal field and oxygen transport in the whole furnace were carried out for two cases with larger inner crucible diameters of $360 \mathrm{~mm}$ and $420 \mathrm{~mm}$, respectively. The melt flow pattern and oxygen distributions in the melt for the two cases are shown in Figure 7. Comparing the results shown in Figures 7 and $3 b$, we can see that when the diameter of the inner crucible was enlarged, the melt flow patterns in the crucibles were similar. However, the $\mathrm{O}$ concentration in the melt between the two crucibles increased while it decreased inside the inner crucible. As a result, the $\mathrm{O}$ concentration at the m-c interface decreased accordingly, as shown in Figure 8, where a comparison is shown 
for $\mathrm{O}$ distributions at the $\mathrm{m}$-c interface for cases with different inner crucible diameters and the case with a single crucible. The oxygen concentration at the $\mathrm{m}-\mathrm{c}$ interface in the case with the inner crucible diameter of $420 \mathrm{~mm}$ was reduced by nearly $40 \%$ from about 20 ppma to about 12 ppma when compared to the case with the inner crucible diameter of $300 \mathrm{~mm}$, and reduced by $25 \%$ from 16 ppma to about 12 ppma when compared to the case of conventional method with a single crucible. This finding is exciting to us because it is very useful to reduce the oxygen impurities in the silicon crystals grown by a CCZ method. Our proposed approach is, therefore, verified as effective.

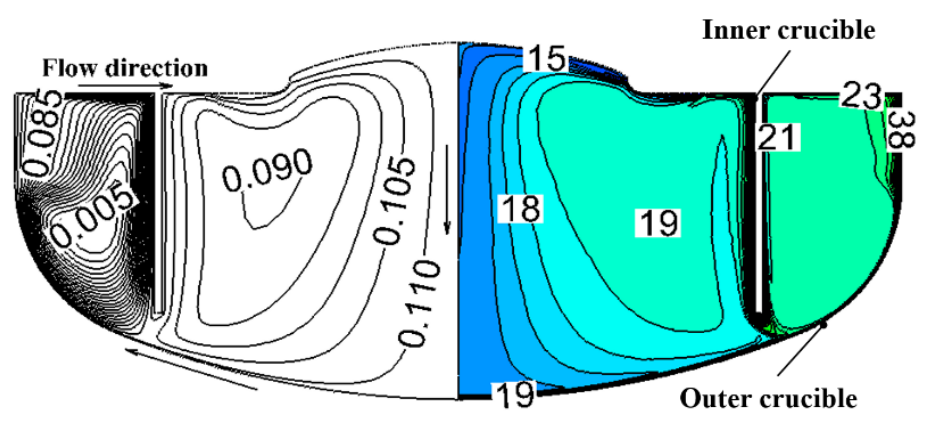

(a) Inner crucible radius of $180 \mathrm{~mm}$

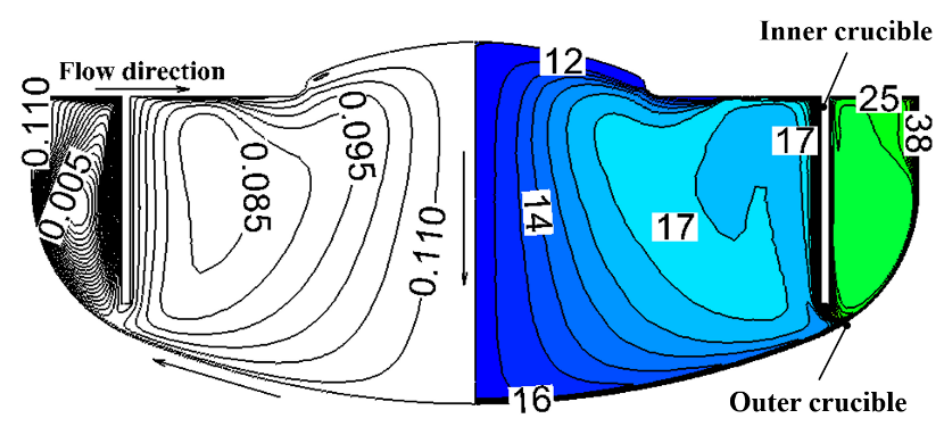

(b) Inner crucible radius of $210 \mathrm{~mm}$

Figure 7. The melt flow patterns (left) and $\mathrm{O}$ distributions (right, ppma) in the melt: (a) the inner crucible radius is $180 \mathrm{~mm},(\mathbf{b})$ the inner crucible radius is $210 \mathrm{~mm}$.

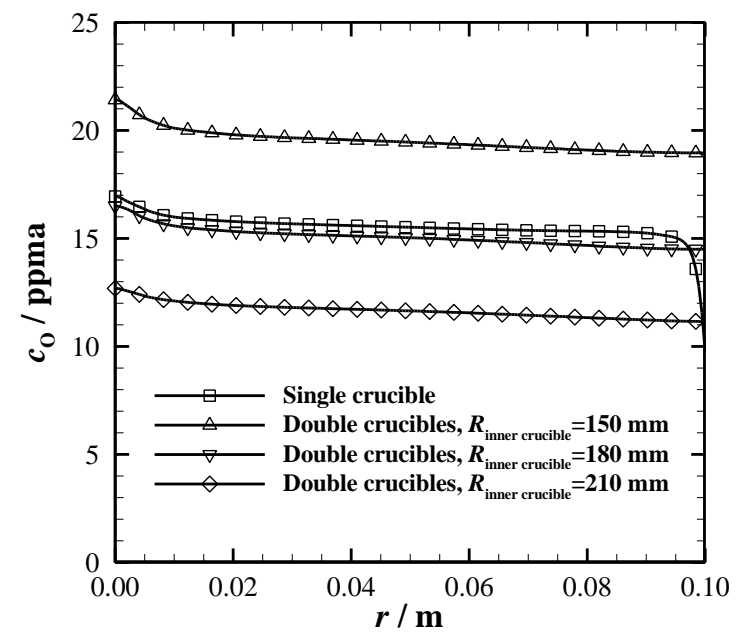

Figure 8. Comparison of $\mathrm{O}$ distributions (ppma) at the $\mathrm{m}-\mathrm{c}$ interface. 


\section{Conclusions}

In this research, a series of global simulations were carried out for a double-crucible $\mathrm{CCZ}$ furnace. The impact of the inner crucible on the $\mathrm{O}$ distribution at the $\mathrm{m}$-c interface was investigated. On the one hand, the inner crucible can prevent the $\mathrm{O}$ impurities dissolved from the outer crucible from transporting to the m-c interface effectively. On the other hand, the inner crucible itself is the main source of $\mathrm{O}$ impurities transported to the $\mathrm{m}-\mathrm{c}$ interface in the melt. We proposed an improved approach with a larger inner crucible diameter to reduce the $\mathrm{O}$ concentration at the $\mathrm{m}$-c interface in a double-crucible CCZ method. The numerical investigation results verified the proposed approach as effective. The $\mathrm{O}$ concentration at the m-c interface can be reduced by $25 \%$ compared to the conventional $\mathrm{CZ}$ method with a single crucible.

Author Contributions: Conceptualization, L.L.; methodology, W.Z. and L.L.; validation, W.Z. and J.L.; formal analysis, W.Z. and L.L.; investigation, W.Z. and L.L.; writing - original draft preparation, W.Z.; writing-review and editing, W.Z., J.L., and L.L. All authors have read and agreed to the published version of the manuscript.

Funding: This research was funded by the National Natural Science Foundation of China (Grant No. 51676154).

Institutional Review Board Statement: Not applicable.

Informed Consent Statement: Not applicable.

Data Availability Statement: Not applicable.

Acknowledgments: The authors gratefully thank the support of National Natural Science Foundation of China (Grant No. 51676154).

Conflicts of Interest: The authors declare no conflict of interest.

\section{References}

1. Kitashima, T.; Liu, L.; Kitamura, K.; Kakimoto, K. Numerical analysis of continuous charge of lithium niobate in a double-crucible Czochralski system using the accelerated crucible rotation technique. J. Cryst. Growth 2004, 266, 109-116. [CrossRef]

2. Kitashima, T.; Liu, L.; Kitamura, K.; Kakimoto, K. Effects of shape of an inner crucible on convection of lithium niobate melt in a double-crucible Czochralski process using the accelerated crucible rotation technique. J. Cryst. Growth 2004, 267, 574-582. [CrossRef]

3. Yoon, Y.; Yan, Y.; Ostrom, N.P.; Kim, J.; Rozgonyi, G. Deep level transient spectroscopy and minority carrier lifetime study on Ga-doped continuous Czochralski silicon. Appl. Phys. Lett. 2012, 101, 222107. [CrossRef]

4. Anselmo, A.; Koziol, J.; Prasad, V. Full-scale experiments on solid-pellets feed continuous Czochralski growth of silicon crystals. J. Cryst. Growth 1996, 163, 359-368. [CrossRef]

5. Ono, N.; Arai, Y.; Abe, K.; Sahira, K. A new technique for controlling the dopant concentration in the double-crucible method. J. Cryst. Growth 1994, 135, 359-364. [CrossRef]

6. Iino, E.; Takano, K.; Kimura, M.; Yamagisi, H. Cavities owing to hydrogen in Si single crystals grown by continuously charging CZ method. Mater. Sci. Eng. B 1996, 36, 146-149. [CrossRef]

7. Giannattasio, A. A simplified model to predict resistivity profiles in continuous-feeding Cz-silicon crystals. J. Cryst. Growth 2020, 542, 125686. [CrossRef]

8. Von Ammon, W. FZ and CZ crystal growth: Cost driving factors and new perspectives. Phys. Status Solidi A 2014, 211, 2461-2470. [CrossRef]

9. $\mathrm{Xu}, \mathrm{H}$. Characterization of n-type mono-crystalline silicon ingots produced by continuous Czochralski (Cz) Technology. Energy Procedia 2015, 77, 658-664. [CrossRef]

10. Xu, H.; Tian, X. Minority carrier lifetime of n-type mono-crystalline silicon produced by continuous Czochralski technology and its effect on hetero-junction solar cells. In Proceedings of the 6th International Conference on Crystalline Silicon Photovoltaics (SiliconPV), Chambéry, France, 7-10 March 2016; Ribeyron, P.J., Cuevas, A., Weeber, A., Ballif, C., Glunz, S., Poortmans, J., Brendel, R., Aberle, A., Sinton, R., Verlinden, P., et al., Eds.; Elsevir: Amsterdam, The Netherlands, 2016; Volume 92, pp. 708-714.

11. International Technology Roadmap for Photovoltaic (ITRPV). Results 2015, 7th ed.; ITRPV: Frankfurt, Germany, 2015.

12. Liaw, H.M. Oxygen and carbon in Czochralski-grown silicon. Microelectron. J. 1981, 12, 33-36. [CrossRef]

13. Kulkarni, M.S. Defect dynamics, in the presence of oxygen in growing Czochralski silicon crystals. J. Cryst. Growth 2007, 303, 438-448. [CrossRef]

14. Kesavan, V.; Srinivasan, M.; Ramasamy, P. Optimizing oxygen impurities using different heater design in the directional solidification of multi-crystalline silicon. Mater. Res. Express 2019, 6, 106323. [CrossRef] 
15. Shao, Y.; Li, Z.; Yu, Q.; Liu, L. Control of melt flow and oxygen distribution using traveling magnetic field during directional solidification of silicon ingots. Silicon 2020, 12, 2395-2404. [CrossRef]

16. Li, Z.; Liu, L.; Ma, W.; Kakimoto, K. Effects of argon flow on impurities transport in a directional solidification furnace for silicon solar cells. J. Cryst. Growth 2011, 318, 304-312. [CrossRef]

17. Teng, Y.-Y.; Chen, J.-C.; Huang, B.-S.; Chang, C.-H. Numerical simulation of impurity transport under the effect of a gas flow guidance device during the growth of multicrystalline silicon ingots by the directional solidification process. J. Cryst. Growth 2014, 385, 1-8. [CrossRef]

18. Gao, B.; Nakano, S.; Kakimoto, K. Global Simulation of Coupled Carbon and Oxygen Transport in a Unidirectional Solidification Furnace for Solar Cells. J. Electrochem. Soc. 2010, 157, H153-H159. [CrossRef]

19. Wang, H.; Liu, L.; Liu, X.; Li, Z. Control of Oxygen Transport in the Melt of a Czochralski-Silicon Crystal Growth. J. Enhanc. Heat Transf. 2012, 19, 505-514. [CrossRef]

20. Smirnov, A.D.; Kalaev, V.V. Development of oxygen transport model in Czochralski growth of silicon crystals. J. Cryst. Growth 2008, 310, 2970-2976. [CrossRef]

21. Liu, X.; Harada, H.; Miyamura, Y.; Han, X.-F.; Nakano, S.; Nishizawa, S.-I.; Kakimoto, K. Transient global modeling for the pulling process of Czochralski silicon crystal growth. II. Investigation on segregation of oxygen and carbon. J. Cryst. Growth 2020, 532, 125404. [CrossRef]

22. Teng, Y.-Y.; Chen, J.-C.; Lu, C.-W.; Huang, C.-C.; Wun, W.-T.; Chen, H.-I.; Chen, C.-Y.; Lan, W.-C. Numerical simulation of the effect of heater position on the oxygen concentration in the CZ silicon crystal growth process. Int. J. Photoenergy 2012, $2012,395235$. [CrossRef]

23. Jomaa, M.; M'Hamdi, M. Effect of crucible diameter on heat transfer and melt flow in continuous czochralski process for silicon crystal growth. In Proceedings of the 27th European Photovoltaic Solar Energy Conference and Exhibition, Frankfurt, Germany, 24-28 September 2012; pp. 1072-1075.

24. Binns, M.J.; Kearns, J.; Good, E.A. (Invited) Impact of oxygen-related defects on lifetime degradation in n-type CCZ/CZ mono-crystalline silicon during cell processing. ECS Trans. 2014, 60, 1233-1238. [CrossRef]

25. Ono, N.; Kida, M.; Arai, Y.; Sahira, K. A numerical study on oxygen transport in silicon melt in a double-crucible method. J. Cryst. Growth 1994, 137, 427-434. [CrossRef]

26. Ono, N.; Trapaga, G. A numerical study of the effects of electromagnetic stirring on the distributions of temperature and oxygen concentration in silicon double-crucible Czochralski processing. J. Electrochem. Soc. 1997, 144, 764-772. [CrossRef]

27. Liu, X.; Gao, B.; Kakimoto, K. Numerical investigation of carbon contamination during the melting process of Czochralski silicon crystal growth. J. Cryst. Growth 2015, 417, 58-64. [CrossRef]

28. Liu, X.; Gao, B.; Nakano, S.; Kakimoto, K. Numerical investigation of carbon and silicon carbide contamination during the melting process of the Czochralski silicon crystal growth. Cryst. Res. Technol. 2015, 50, 458-463. [CrossRef]

29. Matsuo, H.; Ganesh, R.B.; Nakano, S.; Liu, L.; Kangawa, Y.; Arafune, K.; Ohshita, Y.; Yamaguchi, M.; Kakimoto, K. Thermodynamical analysis of oxygen incorporation from a quartz crucible during solidification of multicrystalline silicon for solar cell. $J$. Cryst. Growth 2008, 310, 4666-4671. [CrossRef]

30. Vorob'ev, A.N.; Sid'ko, A.P.; Kalaev, V.V. Advanced chemical model for analysis of Cz and DS Si-crystal growth. J. Cryst. Growth 2014, 386, 226-234. [CrossRef]

31. Bornside, D.E.; Brown, R.A.; Fujiwara, T.; Fujiwara, H.; Kubo, T. The Effects of Gas-Phase Convection on Carbon Contamination of Czochralski-Grown Silicon. J. Electrochem. Soc. 1995, 142, 2790-2804. [CrossRef]

32. Chen, J.-C.; Chiang, P.-Y.; Chang, C.-H.; Teng, Y.-Y.; Huang, C.-C.; Chen, C.-H.; Liu, C.-C. Three-dimensional numerical simulation of flow, thermal and oxygen distributions for a Czochralski silicon growth with in a transverse magnetic field. J. Cryst. Growth 2014, 401, 813-819. [CrossRef]

33. Lan, C. Recent progress of crystal growth modeling and growth control. Chem. Eng. Sci. 2004, 59, 1437-1457. [CrossRef]

34. Liu, L.; Nakano, S.; Kakimoto, K. Investigation of oxygen distribution in electromagnetic CZ-Si melts with a transverse magnetic field using 3D global modeling. J. Cryst. Growth 2007, 299, 48-58. [CrossRef]

35. Liu, L.J.; Kakimoto, K.; Taishi, T.; Hoshikawa, K. Computational study of formation mechanism of impurity distribution in a silicon crystal during solidification. J. Cryst. Growth 2004, 265, 399-409. [CrossRef]

36. Zhao, W.; Liu, L. Control of heat transfer in continuous-feeding Czochralski-silicon crystal growth with a water-cooled jacket. J. Cryst. Growth 2017, 458, 31-36. [CrossRef] 